ISSN: 2162-3104 Print/ ISSN: 2166-3750 Online

Volume 10, Issue S3 (2020), pp. 198-208

(C) Journal of International Students

https://ojed.org/jis

\title{
International Students' Perceptions of Virtual Service Learning Program amidst COVID-19 Pandemic
}

\section{Persepsi Mahasiswa Internasional terhadap Program Kuliah Kerja Nyata Virtual (KKN-V) di Masa Pandemi COVID-19}

\author{
Sitti Nurfaidah \\ Institut Agama Islam Negeri Kendari, Indonesia
}

Anna Riana Suryanti Tambunan

Universitas Negeri Medan, Indonesia

\section{Fadhila Yonata}

Sekolah Tinggi Agama Islam Negeri Sultan Abdurrahman Kepulauan Riau, Indonesia

Dewi Kurniawati

Universitas Islam Negeri Raden Intan Lampung, Indonesia

Reni Puspitasari Dwi Lestariyana

Universitas Sebelas Maret, Surakarta, Indonesia

\begin{abstract}
This article presents two Thai international students' accounts of their lived experiences during a virtual service learning (community service) program due to global COVID-19 pandemic. Semi-structured interview and participants' reflection data were thematically analyzed through the lens of positive and negative emotions so as to explore participants' perceptions of virtual service learning. Findings indicate that the
\end{abstract}


pandemic situation was not a barrier to contributing positively to society. One of the positive effects of the community service activities is that such activities could build students' creativity. It was also found that despite bad internet connectivity in their respective areas, the final-year international students were able to adapt to both academic and non-academic environments. This indicates that all the international students should maintain their positive feelings when completing their service learning program.

ABSTRAK: Artikel ini menyajikan pengalaman dua mahasiswa internasional dari Thailand yang melaksanakan program kuliah kerja nyata virtual (KKN-V) pada masa pandemi COVID-19. Data wawancara semi-terstruktur dan refleksi partisipan dianalisis secara tematik menggunakan perspektif emosi positif dan negatif untuk mengeksplorasi persepsi mereka terhadap program KKN-V. Temuan penelitian ini mengindikasikan bahwa situasi wabah bukan penghalang untuk berkontribusi secara positif kepada masyarakat. Salah satu efek positif dari kegiatan ini adalah dapat meningkatkan kreativitas mahasiswa. Temuan studi ini juga mengungkapkan bahwa meskipun mengalami kendala seperti sinyal internet yang kurang stabil di daerah masing-masing, mahasiswa internasional tingkat akhir mampu beradaptasi dengan lingkungan akademik maupun nonakademik. Dari temuan penelitian tersebut, mahasiswa internasional disarankan agar selalu mempertahankan perasaan positif mereka sampai program $K K N$-V selesai.

Keywords: COVID-19, international students, narrative study, student emotion, virtual service learning [COVID-19, mahasiswa internasional, studi naratif, emosi mahasiswa, kuliah kerja nyata virtual]

\section{PENDAHULUAN}

Sejak virus COVID-19 mewabah, penelitian sebelumnya (Erekson, Bailey, Cattani, Fox \& Goates-Jones, 2020) menunjukkan bahwa beberapa universitas menangguhkan kelas dan layanan mahasiswa untuk memperlambat atau mencegah penyebaran virus COVID-19. Semua universitas beralih dari pembelajaran dan aktivitas pelatihan di luar kampus ke pembelajaran virtual guna memberikan layanan pendidikan kepada para mahasiswanya. Dengan demikian, emosi yang muncul di tengah krisis didominasi oleh emosi negatif (Fredrickson \& Joiner, 2002; Kim \& Niederdeppe, 2013). Hal ini juga berdampak pada kegiatan pengabdian kepada masyarakat, termasuk kuliah kerja nyata $(\mathrm{KKN})$. Dalam situasi pandemik ini, mahasiswa tidak memungkinkan terjun langsung ke masyarakat karena perguruan tinggi menghentikan kegiatan sivitas akademika baik di dalam kampus maupun di luar kampus. Hal ini selaras dengan yang dilaporkan oleh Corbera, Anguelovski, Honey-Rosés dan RuizMallén (2020) bahwa perubahan kegiatan akademik ke moda pembelajaran virtual tidak dapat dihindari selama masa pandemi.

KKN, salah bentuk program pengabdian kepada masyarakat (Helms, Rutti, Hervani, LaBonte \& Sarkarat, 2015), merupakan bentuk kegiatan akademik untuk menerapkan pengetahuan para mahasiswa strata satu. Higher Education 
Research Institute menegaskan bahwa setiap universitas menawarkan kesempatan kepada para mahasiswa untuk terlibat dalam pelayanan atau pembelajaran pengabdian kepada masyarakat setiap tahunnya (Liu, Ruiz, DeAngelo \& Pryor, 2009). Tujuan utama dari program KKN ini adalah untuk mendidik mahasiswa agar bisa bekerja sama dan berdiskusi dengan masyarakat guna menumbuhkan kesadaran berpikir kritis (Seider, 2012). Dengan demikian, mahasiswa diberdayakan untuk memberi kontribusi pengetahuan yang didapat di bangku perkuliahan kepada masyarakat sehingga mereka bisa berperan aktif sebagai agen alih pengetahuan.

Di tengah pandemi COVID-19 ini, program kuliah kerja nyata virtual (KKN-V) harus tetap dilakukan di Indonesia. Pelaksanaan KKN-V ini tentunya memengaruhi emosi mahasiswa, sehingga bisa berdampak terhadap program yang dilakukan (Corbera, Anguelovski, Honey-Rosés \& Ruiz-Mallén, 2020). Penelitian sebelumnya mengeksplorasi kecemasan dan emosi negatif mahasiswa internasional pada tahun awal perkuliahan (Li, Liu, Wei \& Lan, 2013). Dampak kedua emosi tersebut saat ini juga dialami oleh mahasiswa selama pelaksanaan KKN-V di masa pandemi COVID-19. Sebelumnya, proses pembelajaran diintegrasikan dengan pengalaman lapangan dan proses refleksi dilakukan secara langsung atau tatap muka, namun sekarang kegiatan tersebut dilaksanakan secara virtual. Kegiatan KKN-V di masa pandemi COVID-19 ini juga diharapkan berlangsung secara optimal untuk menumbuhkan sikap kepekaan sosial terhadap berbagai masalah yang terjadi di masyarakat. Oleh karena itu, kajian tentang persepsi mahasiswa internasional dalam program pengabdian kepada masyarakat selama masa pandemi COVID-19 perlu dilakukan. Temuan dalam penelitian ini diharapkan dapat berkontribusi untuk pemetaan emosi mahasiswa internasional dalam upaya beradaptasi saat melaksanakan KKN-V di tengah wabah COVID-19.

\section{METODE PENELITIAN}

Penelitian ini mengadopsi pendekatan naratif (Craith, 2012) yang bertujuan untuk mengeksplorasi persepsi dua mahasiswa Thailand yang sedang belajar di salah satu universitas di Sulawesi Tenggara, Indonesia. Mereka merupakan mahasiswa bimbingan penulis pertama yang mengikuti program $\mathrm{KKN}-\mathrm{V}$ pada masa pandemi COVID-19. Kedua partisipan yang berusia 22 tahun ini berasal dari dua kota yang berbeda di Thailand. Ali (nama samaran) berasal dari Narathiwat, sementara Ani (nama samaran) dari Yala (lihat Tabel 1). Mereka bersedia menjadi partisipan dalam penelitian ini secara sukarela.

Tabel 1. Data partisipan dan konten unggahan di media sosial

\begin{tabular}{llllll}
\hline Partisipan & Gender & Asal & $\begin{array}{l}\text { Usia } \\
\text { (tahun) }\end{array}$ & $\begin{array}{l}\text { Semester } \\
\text { ke- }\end{array}$ & $\begin{array}{c}\text { Konten Unggahan } \\
\text { (YouTube, Instagram, } \\
\text { Facebook) }\end{array}$ \\
\hline Ali & Laki-laki & Narathiwat & 22 & 7 & 11 video, 1 poster \\
Ani & Perempuan & Yala & 22 & 7 & 7 video, 5 poster \\
\hline \multicolumn{5}{c}{$-200-$} &
\end{tabular}




\section{Pengumpulan dan Analisis Data}

Proses pengumpulan data dilakukan sejak dimulainya program $\mathrm{KKN}-\mathrm{V}$ pada awal Juli sampai dengan pertengahan September 2020. Program ini diawali dengan pembekalan mahasiswa secara virtual melalui aplikasi Zoom yang diikuti oleh hampir 900 orang yang terdiri atas mahasiswa peserta program, panitia dan dosen pembimbing lapangan (DPL). Sehari setelah pembekalan, DPL mengadakan bimbingan virtual bagi enam belas mahasiswa bimbingannya dengan tujuan mendiskusikan arah dan rencana program kerja KKN-V mereka. Seluruh peserta, termasuk Ali dan Ani, setuju untuk melaksanakan KKN-V dengan pertimbangan bahwa beberapa lokasi di Sulawesi Tenggara termasuk daerah zona merah. Mahasiswa sangat dianjurkan untuk melakukan aktivitas yang tidak melibatkan banyak orang dan mematuhi serta menjalankan protokol kesehatan. Sehari kemudian, mereka berkonsultasi dengan DPL tentang program yang akan mereka laksanakan. Setelah melalui beberapa arahan, kedua partisipan mengajukan beberapa program kerja yang hasilnya akan diunggah di media sosial kelompok dan di media sosial pribadi mereka (lihat Tabel 1). Setelah dua pekan berjalan, DPL melakukan pengawasan dan evaluasi dengan mengajak para partisipan merefleksikan perkembangan program kerja mereka.

Data diperoleh dari catatan reflektif dan wawancara semi-terstruktur. Salah satu penulis meminta mahasiswa untuk menulis catatan reflektif dalam bahasa Indonesia tentang kemajuan kegiatan yang dilakukan selama $\mathrm{KKN}-\mathrm{V}$, misalnya tahap pembekalan, konsultasi perencanaan program kerja, pembuatan konten dan kerja sama tim. Catatan reflektif tersebut digunakan untuk melihat emosi mahasiswa dalam bentuk tulisan. Selanjutnya, catatan tersebut dikirim ke surel salah satu penulis. Setelah mencermati refleksi kemajuan kegiatan mereka, para penulis melihat kecenderungan data emosi positif dan negatif. Akan tetapi, kami belum menemukan hal signifikan terkait emosi mereka saat memilih $\mathrm{KKN}-\mathrm{V}$, sehingga kami melakukan wawancara semi-terstruktur secara virtual melalui pesan WhatsApp (Gibson, 2020). Kami menanyakan apakah mereka sudah memutuskan untuk melaksanakan $\mathrm{KKN}-\mathrm{V}$ sejak sebelum pembekalan. Wawancara ini dilakukan melalui pesan singkat WhatsApp dengan Ali dan Ani pada tanggal 30 Juli 2020 yang berlangsung sekitar satu jam.

Data catatan reflektif dan wawancara dianalisis secara tematik (Braun \& Clarke, 2006) dengan mengadopsi konsep emosi positif (Yih, Kirby \& Smith, 2019) dan emosi negatif (Li, Liu, Wei \& Lan, 2013). Pendekatan tematik ini bertujuan untuk memahami emosi positif yang bisa dilihat dari manfaat $\mathrm{KKN}-\mathrm{V}$ dan emosi negatif yang terlihat dari kendala yang mereka hadapi. Kami membaca data catatan reflektif dan wawancara berulang-ulang agar mudah dalam pengodean untuk menemukan tema terkait emosi positif dan negatif selama KKN-V. Kemudian, kami menginterpretasikan catatan reflektif dan wawancara serta memaknai setiap kata dan kalimat yang ditulis oleh kedua partisipan. 


\section{TEMUAN DAN PEMBAHASAN}

Hasil analisis data menunjukkan dua tema utama, yaitu (1) emosi positif mahasiswa yang mengungkap manfaat yang diperoleh partisipan selama KKN$\mathrm{V}$ dan (2) emosi negatif yang mengungkap kendala yang dihadapi partisipan selama melaksanakan $\mathrm{KKN}-\mathrm{V}$.

\section{Emosi Positif Mahasiswa: "Kami Bisa Menghasilkan Konten Edukatif bagi Masyarakat"}

Program KKN-V merupakan kebijakan program pengabdian kepada masyarakat di perguruan tinggi yang mulai diterapkan pada masa pandemi COVID-19. Ada dua pilihan KKN yang ditawarkan oleh kampus yaitu KKN langsung di zona hijau dan KKN virtual di zona merah. Kegiatan KKN-V merupakan hal baru baik bagi sivitas akademika maupun bagi masyarakat di Indonesia yang berpotensi memengaruhi emosi di tengah wabah (Kim \& Niederdeppe, 2013). Dalam konteks penelitian ini, kedua partisipan menunjukkan alasan yang berbeda pada saat harus memilih $\mathrm{KKN}-\mathrm{V}$. Ani awalnya menghendaki program KKN langsung karena beberapa teman di kelompoknya sudah mendapatkan izin untuk melakukan KKN di salah satu desa di Sulawesi Tenggara. Sebaliknya, sejak awal Ali sudah memilih KKN-V atas saran ayahnya. Namun, setelah melewati proses pembekalan dan konsultasi virtual bersama DPL dan mahasiswa lainnya, kedua partisipan mendapatkan pemahaman sehingga mereka lebih siap menghadapi KKN-V. Narasi emosi positif partisipan dapat dilihat di dalam petikan data jurnal refleksi dan wawancara di Tabel 2.

Kebijakan kampus mengenai penerapan $\mathrm{KKN}-\mathrm{V}$ di zona merah menimbulkan kekecewaan bagi mahasiswa internasional. Contohnya, Ani sudah membayangkan akan melakukan KKN langsung di desa, seperti yang dialami oleh teman-temannya pada tahun sebelumnya. Namun, dia harus mengubah semua rencana yang telah dibuatnya. Hal ini serupa dengan temuan penelitian Kim dan Niederdeppe (2013) yang melaporkan bahwa adaptasi nonakademik dapat menimbulkan kesedihan dan kecemasan bagi mahasiswa dan sivitas akademika lainnya. Seiring dengan berjalannya program, Ani menunjukkan perubahan emosi ke arah positif. Dia menikmati proses pembekalan dan konsultasi virtual karena bisa mendapatkan informasi yang dibutuhkan tanpa harus keluar dari rumah di masa berisiko ini. Ani menikmati proses pelaksanaan program kerja dengan dukungan kerja sama tim dan mengunggah informasi ke media sosial terkait konten yang sedang dibuatnya. Moda virtual memudahkannya menyelesaikan target kerja dengan lebih fleksibel. Narasi Ani menunjukkan bahwa emosi negatif yang diikuti emosi positif berperan penting untuk menghadapi situasi kritis seperti pandemi (Fredrickson \& Joiner, 2002). Data yang menunjukkan emosi positif dan negatif dapat dilihat di Tabel 2. 
Tabel 2. Narasi emosi positif partisipan

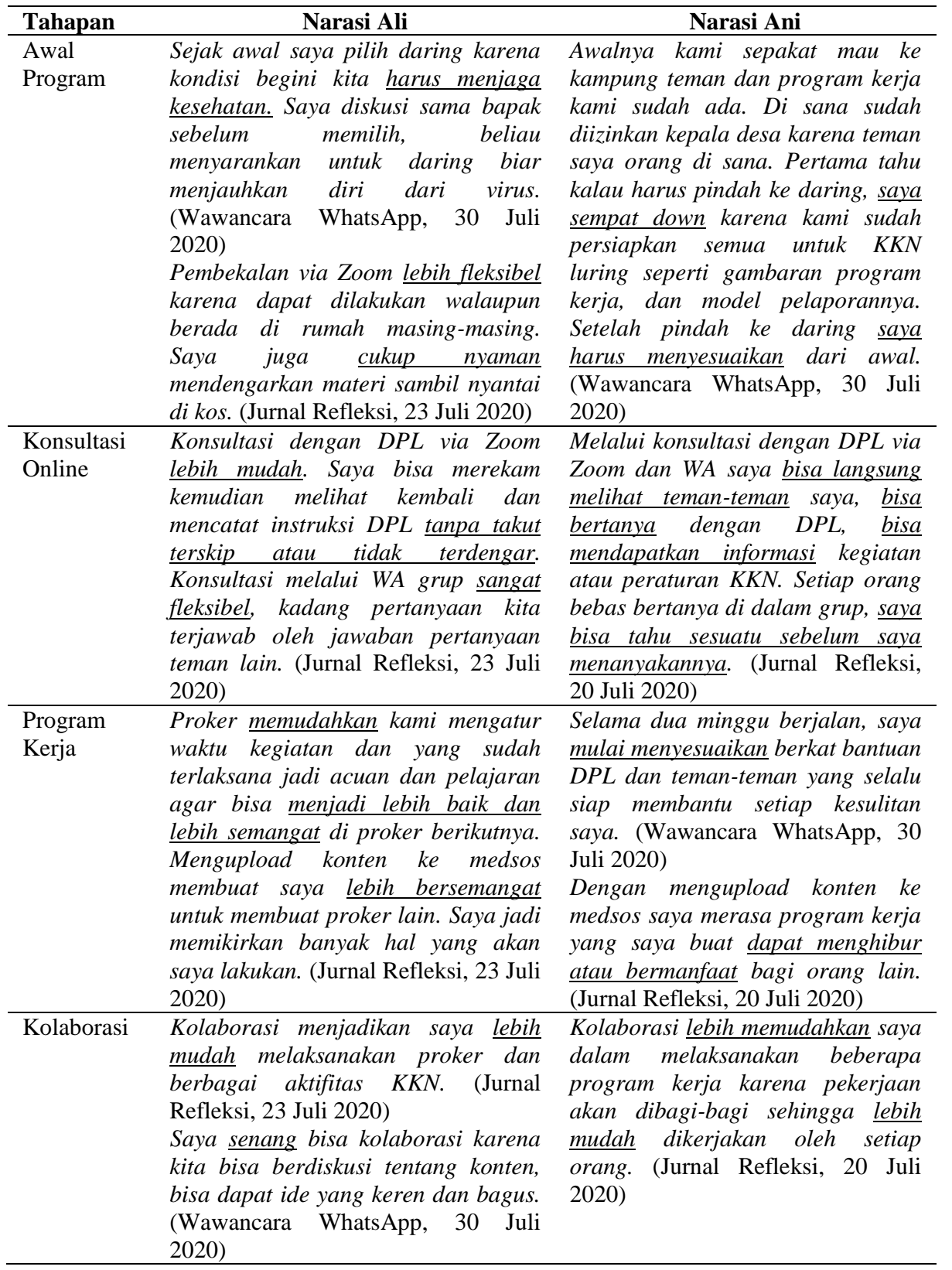

Bagi Ali, KKN-V merupakan kegiatan yang fleksibel karena memberikan kesempatan untuk merencanakan program kerja tanpa terikat oleh waktu dan tempat. Fleksibilitas ini juga membuat dia lebih semangat melaksanakan 
program kerja, apalagi didukung oleh kerjasama kelompok yang cukup baik. Emosi positif Ali ditunjukkan dengan kemampuannya beradaptasi dengan program $\mathrm{KKN}-\mathrm{V}$ yang menuntutnya menghasilkan konten edukasi dan literasi pencegahan COVID-19. Respons positif ini tergambar dalam semangat, perasaan senang dan kemudahan (Yih, Kirby \& Smith, 2019) yang dialami ketika melakukan berbagai hal dalam kegiatan KKN-V.

\section{Emosi Negatif Mahasiswa: "Jaringan Jelek dan Saya Bingung Mau Buat Konten Apa"}

Ani dan Ali mengalami berbagai masalah baik teknis maupun nonteknis dalam pelaksanaan KKN-V di tengah pandemi COVID-19. Dalam narasi emosi negatif yang tertuang di dalam data jurnal refleksi dan wawancara, Ali dan Ani mengakui bahwa koneksi internet yang buruk di musim hujan menjadi kendala teknis yang utama bagi mereka dalam mengunggah konten ke media sosial. Emosi negatif partisipan dapat dilihat di Tabel 3.

Tabel 3. Narasi emosi negatif partisipan

\begin{tabular}{|c|c|c|}
\hline Kendala & Narasi Ali & Narasi Ani \\
\hline Koneksi & $\begin{array}{l}\text { Dalam mengupload update } \\
\text { kegiatan KKN di medsos } \\
\text { kendalanya jaringan yang lemah } \\
\text { saat musim hujan seperti sekarang. } \\
\text { (Jurnal Refleksi, } 23 \text { Juli 2020) }\end{array}$ & $\begin{array}{l}\text { Jaringan kurang baik sehingga } \\
\text { mengupload video terjeda. Dua pekan } \\
\text { hujan terus menerus yang } \\
\text { mengganggu pembuatan video. } \\
\text { (Jurnal Refleksi, 20 Juli 2020) }\end{array}$ \\
\hline $\begin{array}{l}\text { Program } \\
\text { Kerja }\end{array}$ & $\begin{array}{l}\text { Kadang saya bingung menentukan } \\
\text { konteks proker. Saya ingin } \\
\text { melakukannya di sini tapi tidak } \\
\text { memungkinkan, atau ingin } \\
\text { kolaborasi, tapi ada saja kendala. } \\
\text { (Jurnal Refleksi, } 23 \text { Juli 2020) } \\
\text { Saya kurang paham cara } \\
\text { mengambil gambar, mengedit } \\
\text { video, dan menggunakan aplikasi } \\
\text { pengeditan. Rekaman kadang } \\
\text { terkendala cuaca, jika hujan maka } \\
\text { harus pindah hari. (Wawancara } \\
\text { WhatsApp, } 30 \text { Juli 2020) }\end{array}$ & $\begin{array}{l}\text { Saat merencanakan proker, saya sulit } \\
\text { mendapatkan ide-ide. Saat } \\
\text { melaksanakan proker, saya kadang } \\
\text { kurang percaya diri di depan kamera. } \\
\text { Saya harus memberanikan diri untuk } \\
\text { membuat video karena harus } \\
\text { berbicara di depan kamera dan } \\
\text { kadang saya harus membuat video di } \\
\text { tempat umum. (Jurnal Refleksi, } 20 \\
\text { Juli } 2020 \text { ) }\end{array}$ \\
\hline $\begin{array}{l}\text { Manajemen } \\
\text { Waktu }\end{array}$ & $\begin{array}{l}\text { Saya merasa sulit mengatur waktu } \\
\text { dengan tim. Saya free hari ini, } \\
\text { teman saya sibuk. Saya sibuk, } \\
\text { mereka free. (Wawancara } \\
\text { WhatsApp, } 30 \text { Juli 2020) }\end{array}$ & $\begin{array}{l}\text { Kendala dalam teamwork sulit } \\
\text { mengatur waktu dan hari yang tepat } \\
\text { untuk melaksanakan program kerja. } \\
\text { (Jurnal Refleksi, } 20 \text { Juli 2020) }\end{array}$ \\
\hline
\end{tabular}

Selain kendala teknis yang dipaparkan dalam narasi tersebut, Ali dan Ani juga mengalami kendala nonteknis seperti keterbatasan ide, ketidakmampuan menyunting video, kesulitan mengatur waktu dan krisis kepercayaan diri. Ali merasa bingung dalam merencanakan program kerja yang sesuai dengan tema 
edukasi dan literasi pencegahan COVID-19. Selain itu, dia mengalami masalah dalam mengedit video karena kurang menguasai aplikasi terkait. Hal ini menjadi tantangan bagi mahasiswa yang tiba-tiba terpaksa mengikuti KKN-V. Temuan ini sejalan dengan penelitian Helms, Rutti, Hervani, LaBonte dan Sarkarat (2015) yang melaporkan bahwa perubahan moda KKN dari langsung ke virtual menuntut adaptasi mahasiswa terhadap teknologi. Sama dengan Ali, Ani kekurangan ide dalam merencanakan konten yang akan dibuatnya dalam kegiatan KKN-V ini. Selain itu, Ani merasa kurang percaya diri jika tampil di depan kamera. Hal ini menjadi salah satu kendala suksesnya program KKN-V (Helms, Rutti, Hervani, LaBonte \& Sarkarat, 2015). Baik Ali maupun Ani mengalami kesulitan dalam mengatur waktu ketika membuat konten dengan rekan sekelompoknya. Saat mereka mempunyai waktu luang, temannya sedang sibuk atau sebaliknya.

\section{KESIMPULAN}

Penelitian ini mengungkapkan respons emosi positif dan negatif mahasiswa internasional selama mengikuti KKN-V. Dampak positif dari pelaksanaan $\mathrm{KKN}-\mathrm{V}$ ini adalah mahasiswa menjadi lebih kreatif dengan adanya kegiatan mengunggah program kerja masing-masing di media sosial YouTube. Hal ini bermanfaat untuk memberi informasi kepada masyarakat virtual (netizens) mengenai program-program sosial yang dilakukan oleh mahasiswa. Salah satu kendala yang dialami oleh mahasiswa selama $\mathrm{KKN}-\mathrm{V}$ yaitu ketidakstabilan sinyal internet di daerah masing-masing. Dari berbagai pergulatan emosi dan kendala yang dialami oleh mahasiswa selama KKN-V tersebut, dapat disimpulkan bahwa mahasiswa internasional berupaya beradaptasi dengan memunculkan emosi positif demi kelancaran dan kesuksesan kegiatan KKN-V selama masa pandemi COVID-19. Berdasarkan temuan penelitian tersebut, disarankan agar mahasiswa internasional untuk selalu mempertahankan perasaan positif melalui komunikasi yang baik dengan dosen pembimbing lapangan (DPL) dan anggota kelompok supaya kegiatan $\mathrm{KKN}-\mathrm{V}$ mereka berjalan dengan sukses.

Penelitian ini melaporkan hasil yang memberi wawasan baru, tetapi penelitian ini memiliki keterbatasan karena hanya melibatkan dua mahasiswa internasional saja. Penelitian selanjutnya diharapkan dapat melibatkan partisipan dengan jumlah yang lebih banyak. Selain itu, pendekatan yang dilakukan bisa lebih beragam sehingga mendapatkan hasil penelitian yang memberikan wawasan lain terkait dengan adaptasi emosi positif dan negatif mahasiswa internasional dalam kegiatan pengabdian kepada masyarakat. Dengan bantuan dan kerja sama antara DPL dan anggota kelompok lain, partisipan yang awalnya menunjukkan emosi negatif, secara bertahap memunculkan emosi positif sehingga program $\mathrm{KKN}-\mathrm{V}$ mereka berhasil. 


\section{Pernyataan Penulis [Disclosure Statement]}

Para penulis menyatakan bahwa tidak ada konflik kepentingan dalam hal riset, kepengarangan, dan publikasi artikel ini. [The authors declared no potential conflicts of interest with respect to the research, authorship, and/or publication of this article.]

\section{Pernyataan Kontribusi Penulis [Authors' Contribution Statements]}

Sitti Nurfaidah: Mengonsep ide (utama), merancang metode penelitian (utama), menulis artikel awal (utama), mengevaluasi (utama), dan mengedit (setara) [conceptualization (lead), writing-original draft (lead), methodology (lead), review (lead), and editing (equal)]. Anna Riana Suryanti Tambunan: Mengonsep ide (utama), merancang metode penelitian (utama), menulis artikel (utama), mengevaluasi (setara), dan mengedit (setara) [conceptualization (lead), methodology (lead), writing draft (lead), review (equal), and editing (equal)]. Fadhila Yonata: Mengonsep ide (pendukung), merancang metode penelitian (pendukung), menulis artikel (setara), mengevaluasi (setara), dan mengedit (setara) [conceptualization (supporting), methodology (supporting), writing draft (equal), review (equal), and editing (equal)].

Dewi Kurniawati: Mengonsep ide (pendukung), merancang metode penelitian (setara), menulis artikel (setara), mengevaluasi (setara), dan mengedit (pendukung) [conceptualization (supporting), methodology (equal), writing draft (equal), review (equal), and editing (supporting)]. Reni Puspitasari Dwi Lestariyana: Mengonsep ide (pendukung), menulis artikel (setara), mengevaluasi (setara), dan mengedit (pendukung) [conceptualization (supporting), writing draft (equal), review (equal), and editing (supporting)].

\section{DAFTAR REFERENSI}

Braun, V., \& Clarke, V. (2006). Using thematic analysis in psychology. Qualitative Research in Psychology, 3(2), 77-101. DOI: 10.1191/1478088706qp063oa

Corbera, E., Anguelovski, I., Honey-Rosés, J., \& Ruiz-Mallén, I. (2020). Academia in the time of COVID-19: Towards an ethics of care. Planning Theory \& Practice, 21(2), 191-199. DOI: 10.1080/14649357.2020.1757891

Craith, N. (2012). Narratives of place, belonging and language: An intercultural perspective. London: Palgrave Macmillan.

Erekson, D. M., Bailey, R. J., Cattani, K., Fox, S. T., \& Goates-Jones, M. K. (2020). Responding to the Covid-19 pandemic at a university counseling center: Administrative actions, client retention, and psychotherapy outcome. Counselling Psychology Quarterly. Terbit pertama online (hlm. 1-15). DOI: 10.1080/09515070.2020.1807914

Fredrickson, B. L., \& Joiner, T. (2002). Positive emotions trigger upward spirals toward emotional well-being. Psychological Science, 13(2), 172-175. DOI: $10.1111 / 1467-9280.00431$

Gibson, K. (2020). Bridging the digital divide: Reflections on using WhatsApp instant messenger in youth research. Qualitative Research in Psychology. Terbit pertama online (hlm. 1-15). DOI: 10.1080/14780887.2020.1751902

Helms, M. M., Rutti, R. R., Hervani, A. A., LaBonte, J., \& Sarkarat, S. (2015). Implementing and evaluating online service learning projects. Journal of Education for Business, 90(7), 369-378. DOI: $10.1080 / 08832323.2015 .1074150$ 
Kim, H. K., \& Niederdeppe, J. (2013). The role of emotional response during an H1N1 influenza pandemic on a college campus. Journal of Public Relations Research, 25(1), 30-50. DOI: 10.1080/1062726X.2013.739100

Li, J., Liu, X., Wei, T., \& Lan, W. (2013). Acculturation, internet use, and psychological well-being among Chinese international students. Journal of International Students, 3(2), 174-192.

Liu, A., Ruiz, S., DeAngelo, L., \& Pryor, J. (2009). Findings from the 2008 administration of the college senior survey (CSS): National aggregates. Los Angeles, CA: Higher Education Research Institute, UCLA.

Seider, S. (2012). The influence of parental support on the community service learning experiences of American college students. Education, Citizenship and Social Justice, 7(3), 271-288. DOI:10.1177/1746197912456340

Yih, J., Kirby, L. D., \& Smith, C. A. (2019). Profiles of appraisal, motivation, and coping for positive emotions. Cognition and Emotion, 34(3), 1-17. DOI: 10.1080/02699931.2019.1646212

\section{BIODATA SINGKAT PENULIS [NOTES ON CONTRIBUTORS]}

Sitti Nurfaidah adalah dosen di Institut Agama Islam Negeri Kendari, Sulawesi Tenggara, Indonesia. Minat penelitian penulis pada kajian reflektif, psikologi positif dalam pembelajaran bahasa dan umpan balik menulis dalam bahasa Inggris di perguruan tinggi. Email: sittinurfaidah@iainkendari.ac.id

Sitti Nurfaidah is a lecturer at Institut Agama Islam Negeri Kendari, Sulawesi Tenggara, Indonesia. Her major research interests lie in the areas of reflective practice, positive psychology in language learning and teaching, and feedback in L2 writing.Email: sittinurfaidah@iainkendari.ac.id

Anna Riana Suryanti Tambunan (penulis korespondensi) bertugas sebagai dosen di Universitas Negeri Medan. Fokus penelitian penulis adalah pengajaran Bahasa Inggris sebagai bahasa asing, umpan balik dalam menulis secara daring dan komunikasi lintas budaya. Email: annatambunan@unimed.ac.id

Anna Riana Suryanti Tambunan (corresponding author) is a lecturer at Universitas Negeri Medan. Her research interests include teaching English as a foreign language, online feedback on writing, and intercultural communication. Email: annatambunan@unimed.ac.id

Fadhila Yonata adalah dosen di Sekolah Tinggi Agama Islam Negeri Sultan Abdurrahman Kepulauan Riau, Indonesia. Minat penelitian penulis adalah pengajaran bahasa Inggris sebagai bahasa asing, evaluasi buku ajar dan analisa wacana. Email: fadhila.yonata@ stainkepri.ac.id

Fadhila Yonata is a lecturer at Sekolah Tinggi Agama Islam Negeri Sultan Abdurrahman Kepulauan Riau, Indonesia. His research interests lie in teaching English as a foreign language, textbook evaluation, and discourse studies. Email: fadhila.yonata@stainkepri.ac.id 
Dewi Kurniawati adalah dosen bahasa Inggris di Jurusan Pendidikan Bahasa Inggris Universitas Islam Negeri (UIN) Raden Intan Lampung, Indonesia. Bidang minat penulis meliputi metodologi pengajaran bahasa Inggris, teknologi dalam pengajaran bahasa dan pengembangan profesi guru. Email: dewikurniawati@radenintan.ac.id

Dewi Kurniawati is an English language lecturer in the English Education Department of Universitas Islam Negeri (UIN) Raden Intan Lampung, Indonesia. Her areas of interest include language teaching methodology, technology in language teaching, and teacher professional development. Email: dewikurniawati@radenintan.ac.id

Reni Puspitasari Dwi Lestariyana adalah seorang mahasiswa pascasarjana di program Studi Pendidikan Bahasa Inggris di Universitas Sebelas Maret, Surakarta, Indonesia. Penulis sudah menerbitkan karya-karyanya di Journal of Asia TEFL, Indonesian Journal of Applied Linguistics dan Sexuality and Culture. Minat riset penulis mencakup pengajaran bahasa Inggris untuk anak-anak, evaluasi buku teks bahasa, pengembangan profesi guru dan pembelajaran bahasa berbasis teknologi. Email: renidwilestariyana@gmail.com

Reni Puspitasari Dwi Lestariyana is a postgraduate student in the Department of English Education at Universitas Sebelas Maret based in Surakarta, Indonesia. Her publications appeared in the Journal of Asia TEFL, the Indonesian Journal of Applied Linguistics, and Sexuality and Culture. Her research interests are in teaching English to young learners (TEYL), language textbook evaluation, teacher professional development, and technology-enhanced language learning (TELL). Email: renidwilestariyana@gmail.com 